\title{
Insects from light trap: Do they represent total
}

\section{diversity?}

\section{Joshua Matata Kimondiu' ${ }^{1 *}$, A R V Kumar², and K.N. Ganeshaiah ${ }^{1}$}

\author{
${ }^{1}$ Department of Forestry and Environmental Sciences, GKVK 560065, Bangalore India \\ 2 Department of Agricultural Entomology, GKVK 560065, Bangalore India \\ *kjoshuamatata@yahoo.com
}

\begin{abstract}
Insects collected in the light traps over a period of two years in the agroecosystems of GKVK campus represented 13 of the 21 orders of India. Among these orders collected, five orders viz., Coleoptera, Hemiptera, Hymenoptera, Lepidoptera and Diptera were the most predominant. We compared the relative proportions of these five speciose orders with those expected at national and at global levels to test if the light traps collections can be used as a surrogates of national and global diversity of these groups. We found that while orders Coleopteran and Hemipteran insects are over represented, those of Lepidoptera and Hymenoptera are under-represented. We discuss the possible reasons for these differentia representation.
\end{abstract}

Keywords-Insects, light trap, GKVK campus.

\section{INTRODUCTION}

Assessment of diversity is central to ecology and conservation (Whittaker, et al., 2005). Terrestrial arthropods are extremely important ecosystem components since they exert control over the stability and functioning of ecosystems; they are key players in nutrient cycling and also create substantial economic value via ecosystem services such as pollination, parasitization and predation of crop pests, etc. (Pyle et al., 1981). Moreover, terrestrial arthropods are by far the most diverse group of organisms on our planet, as insects alone account for an estimated 57\% of all species living on our planet (Millennium Ecosystem Assessment, 2005). The best approach to collect a wide range of terrestrial arthropods has been a topic of long-lasting debates (Brehm and Axmacher, 2006). When selecting an appropriate sampling method, the most important parameters to be considered are the design of the sampling tools and their costs, as well as the ecological traits and habitat conditions of the target taxa (Gullan and Cranston, 2005). Specific methods are indeed needed to sample different arthropod taxa. For example, pitfall traps are highly useful for ground-dwelling beetles and ants, malaise traps for flies or parasitic wasps, light traps for moths and many other nocturnal insects (Kitching et al., 2001). For this reason, the capture effectiveness of diverse sampling methods and their improvements are continually studied (Sabu and Shiju, 2010).
Light traps capture highly diverse orders of insects like Coleoptera, Hemiptera, Lepidoptera, Diptera, Hymenoptera, etc (Ramamurthy et al., 2010). Earlier studies on insect species diversity and long term monitoring programmes were based on light trap catches (Holloway, 1983, 1987; Taylor, 1978; Taylor et al., 1976; Wolda, 1981 a, b; Wolda and Roubik, 1986). Though several limitations such as un-interrupted power supply or even the very availability of power in remote forest areas, restrict the use of light traps (see Wolda 1981a), they are used widely for studying the abundance of agricultural pests, community structure, population variability, and incidence of density dependence (Gaston and Macardle, 1994).

Though it is known that the light traps sample only the nocturnal insects, in the present study we attempted to assess the efficacy of the light traps used over a two year period in trapping the total insect diversity of an agro ecosystem. While a comprehensive insect profile of the studied ecosystem is not available we tested the extent to which the insects attracted to light traps reflect the overall diversity at the national and global level based on the available information.

\section{MATERIALS AND METHODS}

The study was taken up at Gandhi Krishi Vignana Kendra (GKVK) campus of the University of Agricultural Sciences, Bengaluru, Karnataka State, India. The campus, 
spread over an area of about 1500 acres has several cropping systems such as plantations (mango, guava, citrus, sapota, etc.), dry land farming systems, irrigated crops and even agro-silviculture systems. The rain-fed crops such as cereals, pulses and oilseed crops, horticultural crops such as flowering plants, fruits and vegetable crops such as tomato, bhendi, chillies, etc., are grown during different seasons of the year. Besides, the campus also has several experimental plots covered by soybean, sunflower, minor millets, arid legumes and agro-forestry crops. Surrounding the campus there is very little vegetation as the area is dominated by residential areas.

Funnel and vane type of light trap fitted with a container to collect the insects was set up almost in the middle of the campus. The light source for the trap was a mercury vapour lamp of 165 Watts (make: Philips). Dichlorvos mixed with water in a ratio of 1: 1 served as the killing agent for insects trapped. The traps were run between $8^{\text {th }}$ May, 2015 and $6^{\text {th }}$ December, 2016 at 21 day intervals from 6.00 p.m. to 6.00 a.m. Thus there were totally 26 sampling dates.

The trap catches were initially air dried and sorted. It was not possible to identify all the collected insects' up to the species level. Therefore, based on external morphology, all potential taxa were assigned to different Operational Taxonomic Units (OTUs). These OTUs were assigned to different families and orders.

\section{Comparing diversity of insects at GKVK with global and national level.}

Among the insects collected, five orders viz., Coleoptera, Hemiptera, Lepidoptera, Diptera and Hymenoptera were the most abundant in terms of the OTUs represented; the numbers of OTUs in other orders were very less (Matata, 2017). Therefore, only these five orders were considered for comparison with the global and national level. We hypothesized that if the proportions of these five orders in our collections were similar to those at the national and global level then light traps could be used to assess the overall diversity of insects.

Of the 31 orders of Insects, Zoraptera, Grylloblattodea and Mantophasmatodea are not found in India. Further, Collembola, Protura, Diplura, Archaeognatha and Thysanura are primarily wingless, while all species of Siphonaptera and Phthiraptera are secondarily wingless. Leaving out these orders, it can be anticipated that members of as many as 21 orders are to be found at the light trap. For this, we first computed the proportion of each of these orders as the ratio of their numbers of species of these orders to that of the sum of their numbers. Such proportions were computed for the global level (Ghosh, 1996) and also for the national level (Ghosh, 1996). Using these proportions at the national and global level, we derived the expected numbers of each order and compared them with the observed numbers of OTUs using chi square test.

\section{RESULTS}

From 26 sampling days during the study period of 546 days, 209,098 insects were collected and were classified in to 764 OTUs. These OTUs represented 13 orders of insects, viz., Isoptera, Psocoptera, Neuroptera, Odonata, Mantodea, Blattodea, Trichoptera, Orthoptera, Hymenoptera, Lepidoptera, Diptera, Hemiptera and Coleoptera. Therefore, fifteen of the 28 orders that are expected to be found at the lights had no representation in the light trap catches (Table $1)$.

As many as 740 of the OTUs collected were from the five orders (Table 1) with 351 from Coleoptera, 133 from Hemiptera, 110 from Diptera, 108 from Lepidoptera and 38 were Hymenoptera. Thus Coleoptera represented 45.76 per cent, Hemiptera were 17.34 per cent, Diptera 14.34 per cent, Lepidoptera 14.08 per cent and 4.95 per cent were from Hymenoptera (Figure 1).

These proportions were different from those known at global and national level (Figure 1). Therefore in order to understand the extent of deviation from the general representation we computed the expected number of OTUs for these five orders based on the proportionate representation at global and national level.

Chi-square computation showed that the relative diversity of the five orders collected at GKVK differed significantly from those expected at the global (Chi-square $=$ 90.16; $\mathrm{p}<0.001$ ) and at the national level (Chi-square = 139.03; $\mathrm{p}<0.001$; Table2). Order Coleoptera, Diptera and Hemiptera were found to be over represented while the other two were under represented (Table 2) at GKVK light traps considering both the global and the national levels. Clearly the insect diversity collected at light traps at GKVK did not match the representation of the five most speciose orders at both the national and the global level insect diversity.

The results of the present study suggest that light traps from a single locations may not provide a relative representation of insect diversity across a larger geographical area. This is anticipated because a single locality cannot capture the diversity of the diverse habitats over a large geographic scale. For example as many as 65 species of tiger 
beetles are known from a single stretch of Siliguri to Darjeeling (Pearson and Ghorpade, 1987) owing to continually changing habitats in this stretch. While the entire stretch of Western Ghats is home for less than 300 species, the state of Sikkim alone harbors 689 species of butterflies (Haribal, 2003) again due the habitat diversity created by the altitude variations. Thus the insects from a single locality can be expected to differ from that of a wider geographical area.

Many factors may influence nocturnality in insects. Potentially the night hours being cooler, the cost of flight may be of great importance in being nocturnal in many insects (Price, 1997). Nevertheless, advantages such as avoidance of abiotic stresses (Casy, 1981; Heinrich 1977, Janzen 1973), restricted availability of resources as a mechanism to avoid competition (Sheehan 1994) and possibly predator avoidance (Wcislo et al., 2004; Basset \& Springate 1992, Heinrich 1977) could drive some insects to become nocturnal. Given these potential advantages, do nocturnal insects outnumber diurnal insects? The available records do not always favour this possibility and suggest all the three possibilities of either the diurnal or the nocturnal insects to be relatively more abundant than the other or almost a similar representation of both the groups (Springate and Basset, 1996; Basset and Springate, 1992). However, the relative abundances can vary across taxa and the general idea of herbivores to be more abundant during nocturnal hours seems to be better supported with predatory and parasitic species being more active during day time (Rosenthal, 2004).

Few studies have examined the entire fauna of trapped insects and most studies restrict themselves to single taxonomic groups. As a result, although similar trapping methods are likely to provide more constant relative representation (Kitching et al., 2001), it is unlikely that the results would hold when diverse kinds of habitats are explored. Light trap catches have been rarely examined from this point of view. The results thus suggest that the light trap collections may not be expected to represent total diversity on a gross scale for the above mentioned reasons. Nevertheless, it may be of interest to examine the relative differences between the GKVK collections and that of global and national level diversity.

Order Coleoptera, Diptera and Hemiptera were found to be over represented at GKVK while Lepidoptera and Hymenoptera were under represented. Although, Coleoptera were over represented in the GKVK collections, it is of interest to note that among the five orders considered, it had best match with the global diversity (Table 2), while the difference was maximum when compared to the national level diversity. Further considering the 21 orders expected at lights, the representation of Coleoptera in India seems to be far poorer among all insects, compared to the relative representation of the order at the global level (Table 2). As a result, it is tempting to suggest that the Coleopteran fauna of India seems to be far poorly known, and hardly matches with the global proportions. Further, the relatively large diversity of the phytophages among the Coleoptera may have provided a better representation of the over all diversity of the group at the lights.

Similarly, a substantial proportion of Hymenoptera being parasitic (high abundance of Ichneumonoidea (Shapiro and Pickering, 2000), underrepresentation of the group could be because of the overwhelming diversity of predatory and parasitic species in the order which by and large are expected to be diurnal (Rosenthal, 2004; Springate and Basset, 1996). However, the under representation of Lepidoptera despite having a large proportion of moths (90\% or more) which are all, by and large, herbivores and nocturnal and the over representation of Diptera is enigmatic. General representation of the Lepidoptera in the plains of southern India that are relatively dry could be poorer relative to the more wet habitats such as the Western Ghats and the NorthEastern parts of the country, as exemplified by the diversity of butterflies in the state of Sikkim. Many anthropophilic Diptera are expected to be nocturnal as also the scavengers. Other flower visiting Diptera and midges could potentially be crepuscular or nocturnal (Inouye et al., 2015) and are likely to be trapped at lights. A detailed analysis of the dipterans caught at lights may throw some light on the general ecological features that might be contributing for better representation at lights. But these results are invariant with studies using Malaise traps that expect Diptera to be more abundant (Kitching et al., 2001) and consequently more active during day time. Yet, GKVK campus being quite an island in the midst of a growing city, it is possible that a considerable diversity is trapped in the island situation, which gets reflected in the trap catches. A similar possibility may explain the over representation of Hemiptera. An analysis of the subcategories and the juveniles (Basset and Springate, 1992) may provide a meaningful explanation for the observed results.

These results apparently are a product of both the geographic variations in representation and the variability in the relative diel activity of different taxa. Better appreciation of the results are possible through comparative studies with other ecologically matching environments and a detailed 
analysis of the insects caught in the study at taxonomic subcategories. Such detailed studies will provide better opportunities to evaluate the constancy of the patterns of collections across different taxa and help strengthen the observed results vis-à-vis general patterns of diversity.

Different collecting methods are expected to provide different kinds of samples that can be delineated by taxa. But light traps catch a greater diversity of insects when compared to many other method of sampling; yet few studies have made efforts to assess the overall diversity of all taxa attracted to light and make comparisons with the general diversity patterns. Most studies are target taxa specific and broad comparisons are rare to come by. In the present study, in an insular environment, it was possible to collect representatives of as many as 13 different orders among the possible 21 orders of insects. Potentially a greater diversity of insects by major groups can be found at lights in a more open environment. Thus despite the limitations, the light traps continue to be the choice method of sampling for many groups of insects and in studies to address broad ecological questions. Present investigation further points to many surprising results that call for greater in depth studies to understand and explain the variations found.

Table 1. Number of species in different orders of insects

\begin{tabular}{|c|c|c|c|c|}
\hline S1. No. & Order & $\begin{array}{l}\text { Species / order * } \\
\text { (India) }\end{array}$ & $\begin{array}{c}\text { Species / order * } \\
\text { (World) }\end{array}$ & $\begin{array}{c}\text { Species / order Study site } \\
(\mathrm{GKVK})\end{array}$ \\
\hline 1 & Archaeognatha & 2 & 250 & 0 \\
\hline 2 & Strepsiptera & 8 & 300 & 0 \\
\hline 3 & Mecoptera & 15 & 350 & 0 \\
\hline 4 & Diplura & 16 & 355 & 0 \\
\hline 5 & Protura & 20 & 260 & 0 \\
\hline 6 & Thysanura & 23 & 1250 & 0 \\
\hline 7 & Embioptera & 33 & 200 & 0 \\
\hline 8 & Siphonaptera & 52 & 2000 & 0 \\
\hline 9 & Phasmida & 60 & 2500 & 0 \\
\hline 10 & Psocoptera & 85 & 2500 & 2 \\
\hline 11 & Ephemeroptera & 94 & 2146 & 0 \\
\hline 12 & Plecoptera & 113 & 2100 & 0 \\
\hline 13 & Blattodea & 156 & 4200 & 4 \\
\hline 14 & Mantodea & 161 & 2000 & 3 \\
\hline 15 & Collembola & 200 & 5000 & 0 \\
\hline 16 & Isoptera & 300 & 2000 & 1 \\
\hline 17 & Neuroptera & 315 & 5000 & 2 \\
\hline 18 & Dermaptera & 320 & 1800 & 0 \\
\hline 19 & Phthiraptera & 400 & 3000 & 0 \\
\hline 20 & Odonata & 491 & 5500 & 2 \\
\hline 21 & Thysanoptera & 691 & 6000 & 0 \\
\hline 22 & Orthoptera & 759 & 14491 & 7 \\
\hline 23 & Trichoptera & 812 & 7000 & 6 \\
\hline 24 & Hymenoptera & 5000 & 100000 & 38 \\
\hline 25 & Diptera & 6093 & 96600 & 110 \\
\hline 26 & Hemiptera & 6500 & 80000 & 133 \\
\hline 27 & Lepidoptera & 13000 & 142500 & 108 \\
\hline \multirow[t]{2}{*}{28} & Coleoptera & 15000 & 350000 & 351 \\
\hline & Total & 50719 & 839302 & 767 \\
\hline
\end{tabular}

\footnotetext{
*From Ghosh, 1996.
} 
Table 2.Comparison of the proportions of five speciose orders at GKVK with those of global and national level diversity.

\begin{tabular}{|c|c|c|c|c|c|c|}
\hline $\begin{array}{c}\text { Sl. } \\
\text { No. }\end{array}$ & Order & $\begin{array}{c}\text { No. of } \\
\text { species } \\
\text { observed at } \\
\text { GKVK }\end{array}$ & $\begin{array}{c}\text { No. of species } \\
\text { expected from } \\
\text { national } \\
\text { proportions }\end{array}$ & $\begin{array}{c}\text { No. of species } \\
\text { expected from } \\
\text { Global } \\
\text { proportions }\end{array}$ & $\begin{array}{c}\text { Per cent } \\
\text { deviation from } \\
\text { national level }\end{array}$ & $\begin{array}{c}\text { Per cent } \\
\text { deviation from } \\
\text { global level }\end{array}$ \\
\hline 1 & Hymenoptera & 38 & 77 & 93 & -50.4504 & -59.0181 \\
\hline 2 & Lepidoptera & 108 & 199 & 132 & -45.8364 & -18.2633 \\
\hline 3 & Diptera & 110 & 93 & 90 & 17.7032 & 22.80722 \\
\hline 4 & Hemiptera & 133 & 100 & 74 & 33.40283 & 79.29575 \\
\hline 5 & Coleoptera & 351 & 230 & 325 & 52.56068 & 8.155201 \\
\hline & $\chi^{\mathbf{2}}$ & & $\mathbf{1 3 9 3}^{* *}$ & $\mathbf{9 0 . 1 6 * *}$ & & \\
\hline
\end{tabular}

** Chi square values are significant at $1 \%$

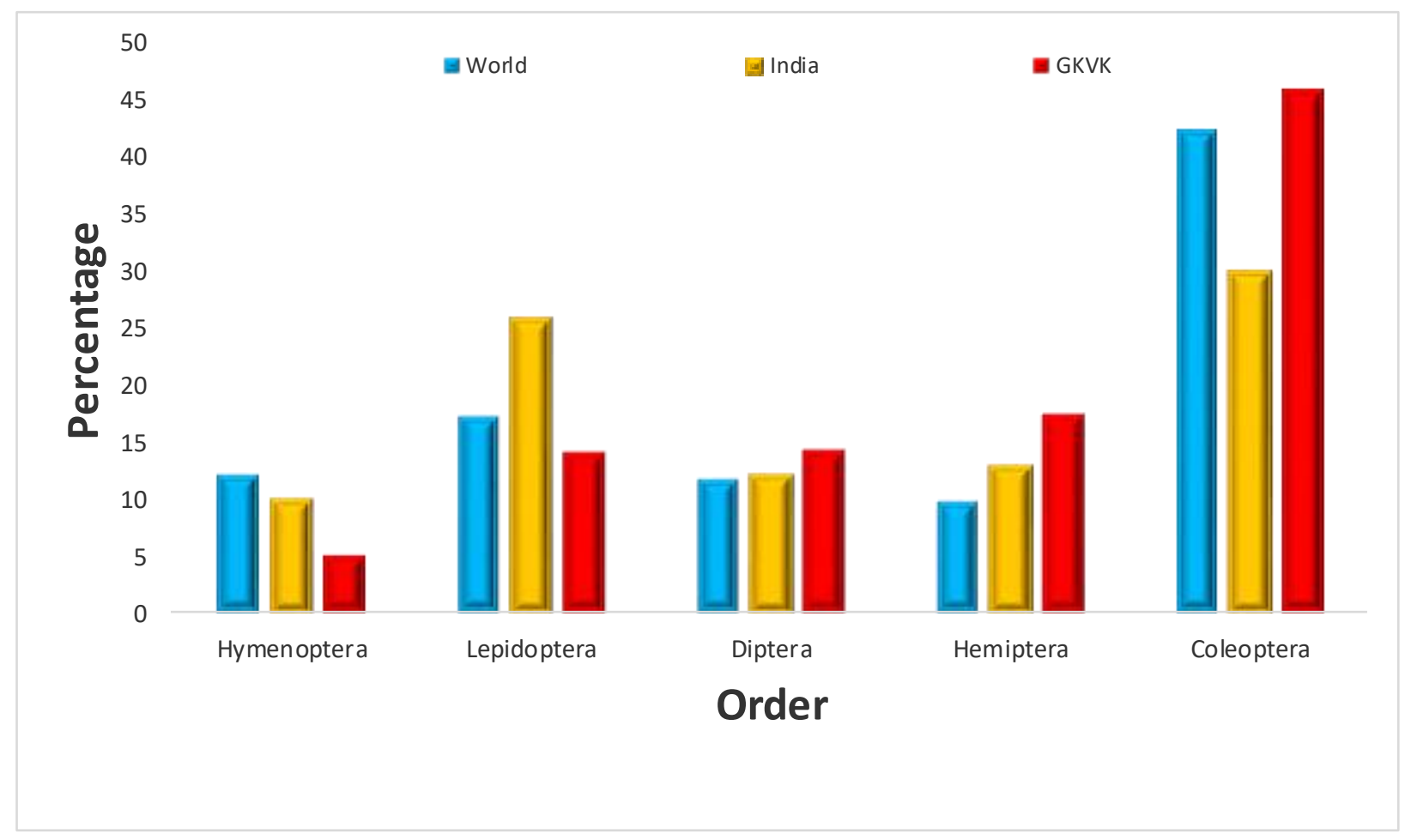

Fig.1: Percent species of the five orders of insects at global, national and at GKVK campus. These values are computed as a percent of the total number of species in 21 of the 31 potential orders that are expected to be attracted to light.

\section{REFERENCES}

[1] ABELE, L.G., 1976, Comparative species richness in fluctuating and constant environments: coral-associated decapod crustaceans. Science, 192: pp. 461-463

[2] BENNETT, A.F., LENSKI AND R.E., 2007, An experimental test of evolutionary trade-offs during temperature adaptation. Proc. Natl. Acad. Sci. U.S.A. 104, 8649-8654.

[3] BASSET, Y.T. and SPRINGATE, N. D., 1992, Diel activity of arboreal arthropods associated with a rainforest tree. Journal of Natural History, 26: 947-952.
[4] BREHM, G. AND AXMACHER, J. C., 2006, A comparison of manual and automatic moth sampling methods (Lepidoptera: Arctiidae, Geometridae) in a rain forest in Costa Rica. Environmental Entomology, 35: 757-764.

[5] CASEY, T. M. 1981. Behavioral mechanisms of thermoregulation. In Heinrich, B. (Ed.). Insect Thermoregulation, pp. 90-110. A Wiley-Interscience Publication: New York.

[6] GASTON, K. J. AND MACARDLE, B. H., 1994, The temporal Variablity of Animal Abundances: Measures, 
Methods and Patterns. Philosophical Transactions of the Royal Society of London, series B, 345: 335-358.

[7] GOSH, A. K., 1996, Insect biodiversity in India, Oriental insects, 30: 1-10

[8] GULLAN, P. J. AND CRANSTON, P. S., 2005. The insects: an outline of entomology. Chapter 17, Methods in entomology: collecting preservation, curation, and indentification. Hoboken, NJ: Wiley-Blackwell.

[9] HARIBAL, M., 2003. Butterflies of Sikkim Himalaya and Their Natural History, Natraj Publishers, p. 217.

[10] HEINRICH, G.H., 1977. Ichneumonidae of Floridaand neighbouring states (Hymenoptera : Ichneumonidae, subfamily Ichneumoninae). Arthropods of Florida and neighbouring land Areas, $9: 1-350$.

[11] HOLLOWAY, J.D., 1983, Insect surveys -An approach to environmental monitoring. AlliXllCongr. Naz. Ital. Entomol., Roma, 239-261.

[12] HOLLOWAY, J. D., 1987, Macrolepidoptera diversity in the Indoaustralian tropics: Geographic, biotopic and taxonomic variations. Biol. J. Linnean Soc. 30: 325-J41.

[13] INOUYE, D. W., BRENDON, M. H., LARSON, A. S. AND PETER, G. K., 2015, Flies and flowers iii: ecology of foraging and pollination. Journal of Pollination Ecology, 16: $115-133$

[14] JANZEN, D. H., 1973, Sweep samples of tropical foliage insects: effects of seasons, vegetation types, elevation, time of day and insularity, Ecology, 54: 687-708.

[15] KITCHING, R., LI, D. L. AND STORK, N. E., 2001. Assessing biodiversity sampling packages: how similar are arthropod assemblages in different tropical rainforests? Biodiversity and Conservation, 10: 793-813.

[16] MATATA, J. K., GYANESHWAR, JHA, KUMAR, A. R. V. AND GANESHAIAH, K. N., 2017, Temporal patterns of insect diversity in Bengaluru: A study using light traps. The Mysore Journal of Agricultural Sciences, 51: 78-84.

[17] MILLENNIUM ECOSYSTEM ASSESSMENT., 2005, Ecosystems and human wellbeing: Biodiversity synthesis. Washington, DC: World Resources Institute.

[18] PEARSON, D.L. AND GHORPADE K., 1987 Tiger Beetles (Coleoptera : Cicindelidae) of the Siliguri-Darjeeling area in India, Colemania, 4: 1-22.

[19] PRICE, P.W. 1997. Insect Ecology. John Wiley and Sons, Inc., New York, New York, USA.

[20] PYLE, R., BENTZIEN, M. AND OPLER, P., 1981, Insect conservation. Annual Review of Entomology, 26: 233-258.

[21] RAMAMURTHY, V. V., AKHTAR, M. S., PATANKAR, N., MENON, P., KUMAR, R. AND SINGH, S. K., 2010, Efficiency of different light sources in light traps in monitoring insect diversity. MunEntZool, 5:109-114.

[22] ROSENTHAL, M.,2004. Nocturnal vs. diurnal insect diversity within tropical montane forest canopy http://digital.lib.usf.edu/SFS0001569/00001/pdf; date retrieved 11/28/2017.
[23] SABU, T. K. AND SHIJU, R. T., 2010, Efficacy of pitfall trapping, Winkler and Berlese extraction methods for measuring ground-dwelling arthropods in moist-deciduous forests in the Western Ghats. Journal of Insect Science, 10: 117.

[24] SHAPIRO, B. A., AND PICKERING, J., 2000. Rainfall and parasitic wasp (Hymenoptera: Ichneumonoidea) activity in successional forest stages at Barro Colorado Nature Monument, Panama, and La Selva Biological Station, Costa Rica. Agric. For. Entomol. 2 : 1-9.

[25] SHEEHAN, W. 1994. Parasitoid community structure: effects of host abundance, phylogeny, and ecology. In B. A. Hawkins and W. Sheehan (Eds.). Parasitoid Community Ecology, pp. 90-102. Oxford University Press: Oxford.

[26] SPRINGATE, N.D. AND BASSET, Y., 1996, Diel activity of arboreal arthropods associated with Papua New Guinean trees Journal of Natural History, 30: 101-112.

[27] TAYLOR, L. R., 1978, Bates, Williams, Hutchinson - a variety of diversities. In: Mound, L.A., Waloff,N. (eds) Diversity of insect faunas. Symp. Roy. Entomol. Soc. London IX,BladcweU, Oxford, London, Edinburgh, Melboume, pp. 118.

[28] TAYLOR, L. R., KEML'RON, R. A. AND WOIWOO, L. P., 1976, Diversity statistics and the log series model.J. Anim. Ecol. 45: 255- Z12.4.

[29] WCISLO, W.T., ARNESON, L., KARI ROESCH, K., †, VICTOR GONZALEZ, V., ADAM SMITH, A. AND HERMÓGENES FERNÁNDEZ, H., 2004. The evolution of nocturnal behaviour in sweat bees, Megalopta genalis and $\mathrm{M}$. ecuadoria (Hymenoptera: Halictidae): an escape from competitors and enemies? Biological Journal of the Linnean Society, 83: 377-387.

[30] WHITTAKER, R. J., MIGUEL, B. A., JEPSON, P.,LADLE, R.J.,JAMES, E. M., WATSON,K AND WILLIS, J., 2005, Conservation Biogeography: assessment and prospect Mansfield Road, Oxford, OX1 3TB, UK.

[31] WOLDA, H., 1981a, Long-term ecologicalstudies with lighttraps: their practical and scientific value. UttarPradeshJ. 'Zool. 1: 1-5.

[32] WOLDA, A. H., 1981 b, Similarity indices, sample size and diversity. Oecologia (Berlin) 50: 296-302

[33] WOLDA, H. AND ROUBIK, 0. W., 1986, Nocturnal bee abundance and seasonal bee activity in a Panamanian forest. Ecology 67:426-433. 